\title{
OSTEOTOMY OF THE TIBIA AND FIBULA IN THE TREATMENT OF CHRONIC OSTEOARTHRITIS OF THE KNEE
}

\author{
E. N. Wardle, M.Ch.(Orth.), F.R.C.S. \\ Consulting Orthopadic Surgeon, United Liverpool Hospitals.
}

\section{Nihil Scriptum Miraculi Causa}

Osteotomy of the tibia alone as an operation simply to correct deformity at the knee was described and performed by Volkmann as long ago as 1875; at about the same time as Lister and MacEwan (1878) gave their description of the first supracondylar osteotomy. This operation is also mentioned in Orthopædic Surgery (Jones \& Lovett, 1929) in relation to the treatment of knock-knee and bow-leg deformity in adult patients who had suffered from rickets in childhood. This procedure, modified in that the bone is divided horizontally through the inner tuberosity just distal to the articular surface, has been advocated within quite recent years by Smillie (1946). It is also mentioned by Judet, Judet, Lagrange and Dunoyer (1954). My colleague G. E. Thomas (1964) also regards it as correct practice in patients whose painful arthritic knees show a valgus deformity and maintains that this deformity can be corrected by a tibial osteotomy alone.

Osteotomy of the tibia combined with division of the fibula was first performed, to my knowledge, at the Royal Southern Hospital, Liverpool, from 1928 onwards. The surgeons who practised it at that time had usually to deal with deformity of the knee in adults, the result of childhood rickets. This was common in those times. They pointed out that correction of this deformity in adult life by femoral osteotomy, which was so successful in children, invited the rapid onset of pain and chronic degenerative change in the knee joint. They gave the reason that correction of the deformity above the knee joint altered the inclination of the axis of movement of that joint to the line of weightbearing in the leg as a whole; and that whereas a growing child could accommodate to this, an adult could not. Osteotomy below the knee makes no such alteration but corrects the position by the production of an equal and opposite deformity below the original one and leaves the axis of movement of the knee $\vec{\omega}$ joint at the same inclination to the weight $\frac{}{0}$ bearing line of the limb.

The application of this procedure to the treatment of chronic osteoarthritis of the knee is of later date. It is described by Steindler $\stackrel{\circ}{\circ}$ (1940). As far as the series of patients quoted of in this article is concerned the operation was o first performed in 1941 with the single objective 은 of correction of increasing deformity in pain- $\vec{D}$ ful and progressive degeneration of the knee. $\mathbb{\Phi}$ At that time certain authorities regarded this $\frac{\bar{D}}{\mathbb{D}}$ operation as dangerous because of the pos- 3 sibility of vascular complications and even gangrene of the limb, which had bees observed to occur in certain fractures involving $\mathscr{S}$ the tuberosities of the tibia and the proxima shaft of the fibula. This catastrophe need not 0 be anticipated provided proper care is exercised. The rapid relief of pain observed in patients treated in this manner led to the increasing $\stackrel{0}{\circ}$

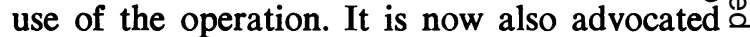
by other authors (Jackson \& Waugh, 1961) $\overrightarrow{\overrightarrow{0}}$ and a proportion of the patients described here 3 have previously been reported elsewhere (Wardle, 1962).

\section{Material}

The majority of the 35 patients (Table 1) reported here presented with osteoarthritic knees in which 3 . varus deformity was associated with persistent and intractable pain which suddenly increased beyond $\mathrm{O}$ that which they had been accustomed to bear for years with the aid of analgesics and physiotherapy. 을 It is plain from other authors that as many patients may present with valgus deformity. Their ages have $\frac{0}{0}$ ranged from 42 to $75 ; 19$ of them were men and 16 women. Pain and deformity were constantly $N$ associated with gross synovial thickening, periodic ${ }^{\circ}$ effusion of fluid in the joints and coarse creaking. $N$ The range of active movement present before treat- N ment has rarely been less than 90 degrees of flexion $\omega$ from the extended position. The radiographs (Fig. 1)을 illustrate a typical knee joint at the time of operation. 0

\section{Technique}

Two skin incisions are used. The first com- $\frac{0}{0}$ mences just distal to the tibial tubercle and $\frac{0}{\Phi}$ 
TABLE 1

\begin{tabular}{|c|c|c|c|c|c|}
\hline Name & $\begin{array}{c}\text { Age at } \\
\text { Operation }\end{array}$ & Deformity & $\begin{array}{c}\text { Period of } \\
\text { Immobilisation } \\
\text { of Knee }\end{array}$ & \begin{tabular}{|c} 
Post-operative \\
Range \\
of Movement
\end{tabular} & \\
\hline $\begin{array}{l}\text { Mrs. T. } \\
\text { Miss L. } \\
\text { Mrs. B. } \\
\text { Mr. P. } \\
\text { Mr. B. } \\
\text { Mr. W. } \\
\text { Mr. B. } \\
\text { Mr. W. } \\
\text { Mr. D. } \\
\text { Mrs. M. } \\
\text { Mrs. N. } \\
\text { Mr. B. } \\
\text { Mrs. C. } \\
\text { Mr. K. } \\
\text { Mr. A. } \\
\text { Mr. McP. } \\
\text { Mrr. H. } \\
\text { Mr. D. } \\
\text { Mr. L. } \\
\text { Mr. K. } \\
\text { Mrs. B. } \\
\text { Mrs. A. B. } \\
\text { Mrs. C. } \\
\text { Mr. P. } \\
\text { Miss P. } \\
\text { Mrs. K. } \\
\text { Mr. H. } \\
\text { Mr. T. } \\
\text { Mr. W. } \\
\text { Mrs. C. } \\
\text { Mrs. R. } \\
\text { Mrs. McD. } \\
\text { Mr. H. J. } \\
\text { Mrs. P. D. } \\
\text { Mr. E. Y. }\end{array}$ & $\begin{array}{c}63 \\
50 \\
65 \\
70 \\
60 \\
68 \\
65 \\
43 \mathrm{R}: 51 \mathrm{~L} \\
63 \\
62 \\
71 \\
42 \\
66 \\
50 \\
61 \mathrm{~L}: 62 \mathrm{R} \\
59 \\
54 \\
50 \\
50 \\
62 \mathrm{~L}: 63 \mathrm{R} \\
73 \\
60 \\
72 \\
61 \\
54 \\
61 \\
58 \\
67 \\
49 \\
67 \\
56 \\
55 \\
75 \\
74 \\
60\end{array}$ & $\begin{array}{l}\text { Varus } \\
\text { Varus } \\
\text { Varus } \\
\text { Varus } \\
\text { Varus } \\
\text { None } \\
\text { Varus } \\
\text { Varus: Varus } \\
\text { Varus } \\
\text { Varus } \\
\text { Varus } \\
\text { Varus } \\
\text { Valgus } \\
\text { Varus } \\
\text { Varus : Varus } \\
\text { Varus } \\
\text { Valgus } \\
\text { Varus } \\
\text { Varus } \\
\text { Varus: Varus } \\
\text { Varus } \\
\text { Valgus } \\
\text { Varus } \\
\text { Varus } \\
\text { None } \\
\text { None } \\
\text { Varus } \\
\text { Varus } \\
\text { Varus } \\
\text { Varus } \\
\text { None } \\
\text { Varus } \\
\text { None } \\
\text { Varus } \\
\text { Varus }\end{array}$ & $\begin{array}{c}8 \text { Weeks } \\
12 \text { Weeks } \\
8 \text { Weeks } \\
8 \text { Weeks } \\
8 \text { Weeks } \\
8 \text { Weeks } \\
12 \text { Weeks } \\
12 \text { Weeks : } 7 \text { Months } \\
12 \text { Weeks } \\
12 \text { Weeks } \\
16 \text { Weeks } \\
12 \text { Weeks } \\
12 \text { Weeks } \\
12 \text { Weeks } \\
8 \text { Weeks : } 10 \text { Weeks } \\
8 \text { Weeks } \\
12 \text { Weeks } \\
12 \text { Weeks } \\
10 \text { Weeks } \\
12 \text { Weeks : } 8 \text { Weeks } \\
12 \text { Weeks } \\
8 \text { Weeks } \\
8 \text { Weeks } \\
8 \text { Weeks } \\
8 \text { Weeks } \\
8 \text { Weeks } \\
8 \text { Weeks } \\
8 \text { Weeks } \\
8 \text { Weeks } \\
8 \text { Weeks } \\
8 \text { Weeks } \\
10 \text { Weeks } \\
12 \text { Weeks }\end{array}$ & $\begin{array}{c}90^{\circ} \\
90^{\circ} \\
\text { Full } \\
\text { Full } \\
\text { Full } \\
90^{\circ} \\
\text { Full } \\
\text { Full : Full } \\
90^{\circ} \\
90^{\circ} \\
\text { Full } \\
\text { Full } \\
90^{\circ} \\
90^{\circ} \\
70^{\circ}: 90^{\circ} \\
90^{\circ} \\
100^{\circ} \\
90^{\circ} \\
\text { Full } \\
70^{\circ}: 100^{\circ} \\
70^{\circ} \\
90^{\circ} \\
45^{\circ} \\
\text { Less than } 90^{\circ} \\
\text { None } \\
\text { Full } \\
\text { Full } \\
45^{\circ} \\
\text { Less than } 90^{\circ} \\
\text { Lhan } 90^{\circ} \\
90^{\circ} \\
\text { Full } \\
90^{\circ} \\
\text { Less }\end{array}$ & $\begin{array}{l}\text { Coronary Incident } \\
\text { Rheumatoid } \\
\text { Death from Coronary } \\
\text { Thrombosis }\end{array}$ \\
\hline
\end{tabular}

extends distally for three inches, curving a little laterally so that at no time does it lie directly over the subcutaneous border of the tibia. The flap thus marked is reflected medially to expose the crest of the tibia and its subcutaneous surface at a point two inches distal to the tibial tubercle. The lateral surface of the tibia is cleared of muscle by a rougine and a bone lever inserted until its tip passes around the posterior border of the bone. A second bone lever is inserted at the medial border of the subcutaneous surface of the tibia in a similar manner. The line of osteotomy is then notched out of the hard cortical bone, particularly at the subcutaneous border, to prevent splintering and the tibia is then divided. The second incision is made on the lateral surface of the leg directly over the shaft of the fibula and at the same level as the first. The fascia is divided in the same line and the peroneal muscles are separated by blunt dissection to avoid damage to the branches of the peroneal nerve; bone levers are inserted and the fibula divided a little distal to the site of the tibial osteotnmy. The operation can be performed easily without a tourniquet in elderly patients. After closure of the incisions any deformity present is corrected and a long leg plaster cast is applied. Clinical union may be expected in six to eight weeks and can be expedited by encouraging the patient to bear weight on the cast. A below knee plaster is substituted when union is present. Internal fixation may be used to avoid plaster fixation but it is doubtful whether patients achieve weight bearing any earlier or recover their movement any more quickly by this method.

\section{Immediate Results}

All patients in this series have reported complete relief of their pain, in particular of their intractable night pain, within a few days 


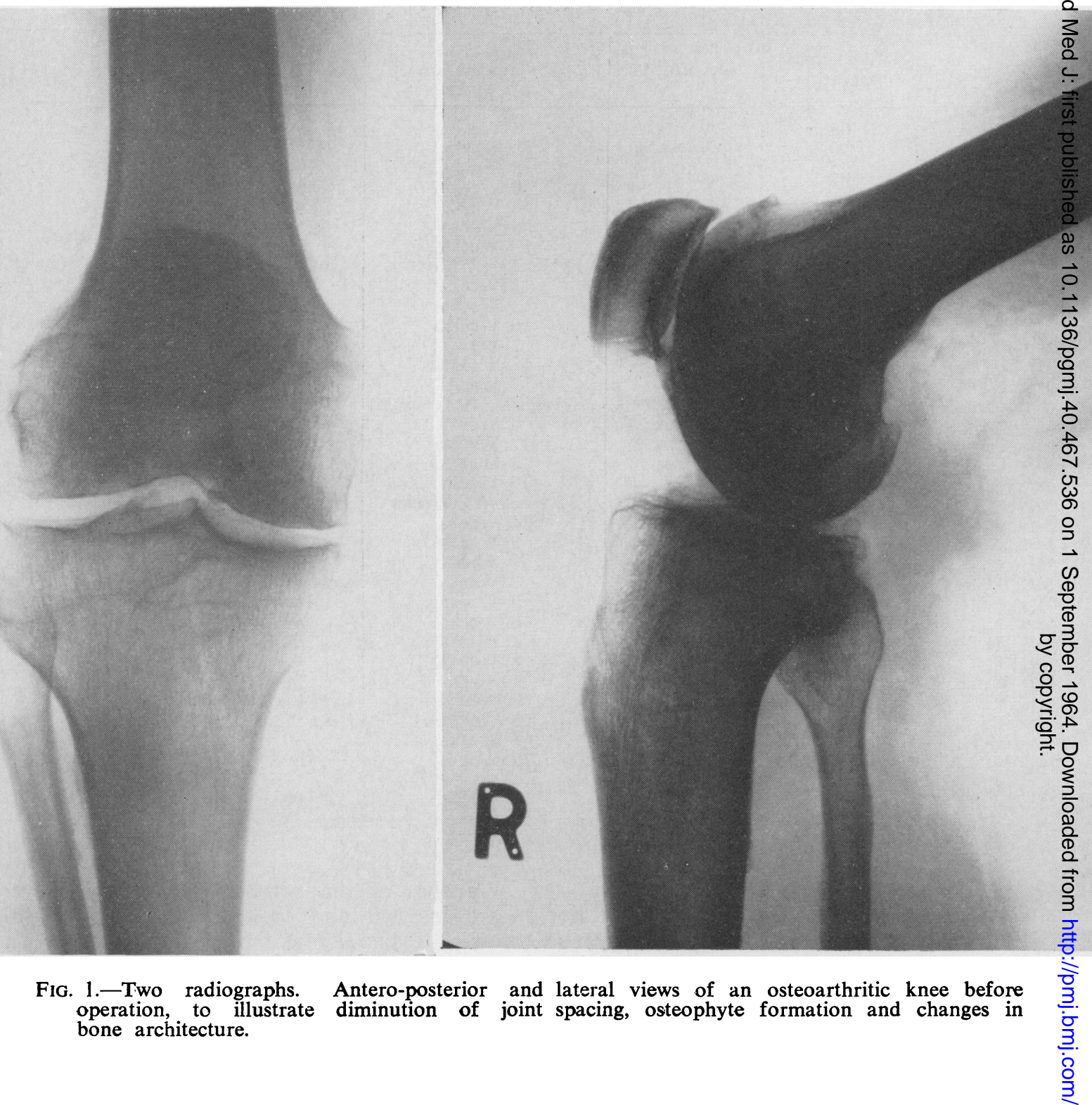

of operation and there has been no recurrence. Twenty-seven of these patients had recovered the minimum range of 90 degrees of active flexion in the knee joint by six months from the time of operation, many of them at three months. A considerable proportion have achieved a full range although movement was limited before operation. At an interval of two years the disappearance of synovial thickening is a striking feature and crepitus is markedly diminished. Later, radiological changes occur in the proximal part of the tibia. Normal bone architecture and density re-appear and cysts disappear (Fig. 2).

\section{Complications}

There have been no immediate complications in any of these patients during the first fouf post-operative weeks, which is in keeping with a simple operation. The advanced age of manye patients would lead one to expect a numbero of coronary thromboses and pulmonaryo emboli. However there have been only three such events, in patients numbered 14, 18 and 29 , all of them comparatively young men. 


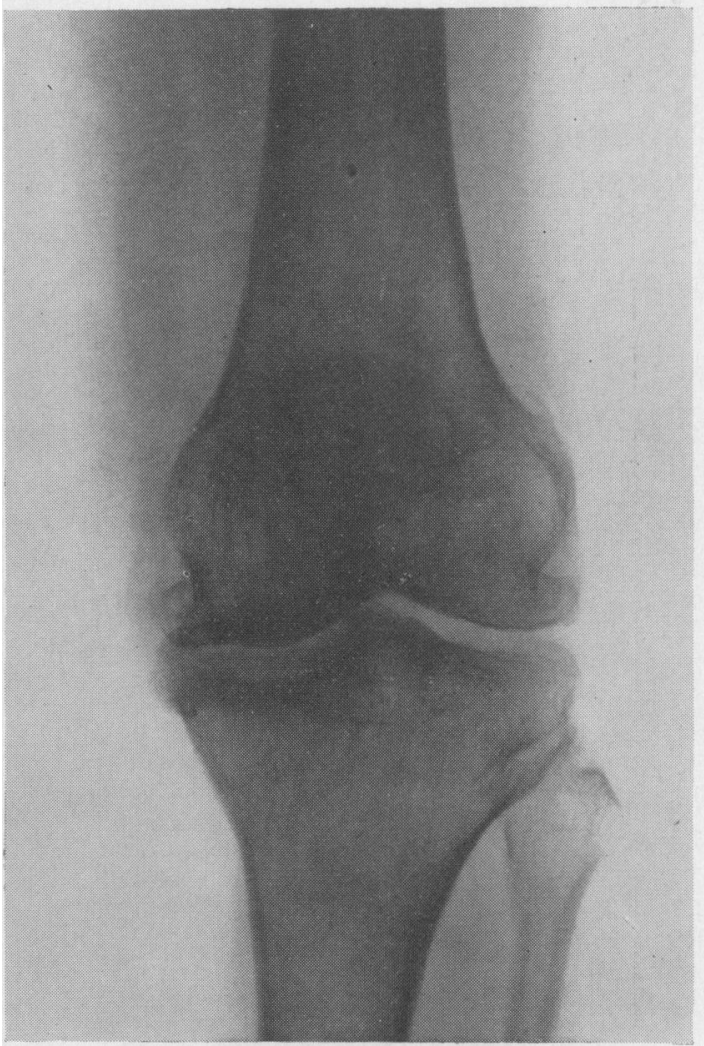

(a)

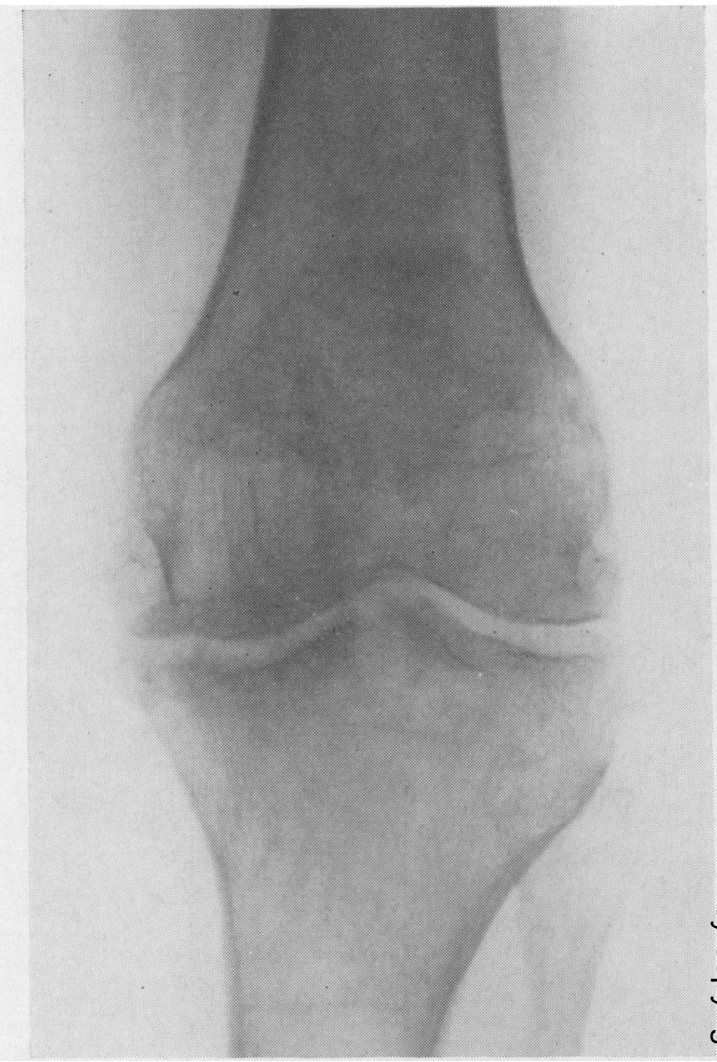

(b)

FIG. 2.-Two radiographs. Antero-posterior views of a knee joint.
(a) 31.7.61 - before operation.
(b) 17.12.62-the same knee joint eighteen months
later, to illustrate the change in joint spacing, bone architecture and density.

\section{Non-Union}

This has been observed once. The patient, young in years but with advanced degenerative changes in his knee joints, presented in 1949. Osteotomy of the tibia and fibula was performed on the left leg at that time. The result was sufficiently successful to return him to work and to bring him back requesting the same procedure for his right knee in 1957. When observed in 1962 there was non-union of the right tibia at the site of the osteotomy, but he was pain free and had a range of 120 degrees of active flexion from full extension in both knees. He was at work and walked without sticks.

\section{Oedema of the Leg}

All patients have shown this in the first few weeks following removal of all external support from the limb. A firm bandage, remedial exercises, periodic elevation of the limb and effleurage together with a graduated increase in the period of weight bearing have usually been sufficient to remove the swelling rapidly. The three patients with cardiovascular complications were notable exceptions.

Wound Infection: This has not occurred in this series.

Muscle Hernia: There have been two examples of this. Both patients had gross deformity and were obese, and it was found impossible to close the fascial envelope of the peroneal muscles at the fibular incision without gross tension.

\section{Late Results}

In patients examined more than five years from the time of operation certain phenomena have been consistently observed. Clinically there is a striking reduction in soft-tissue 


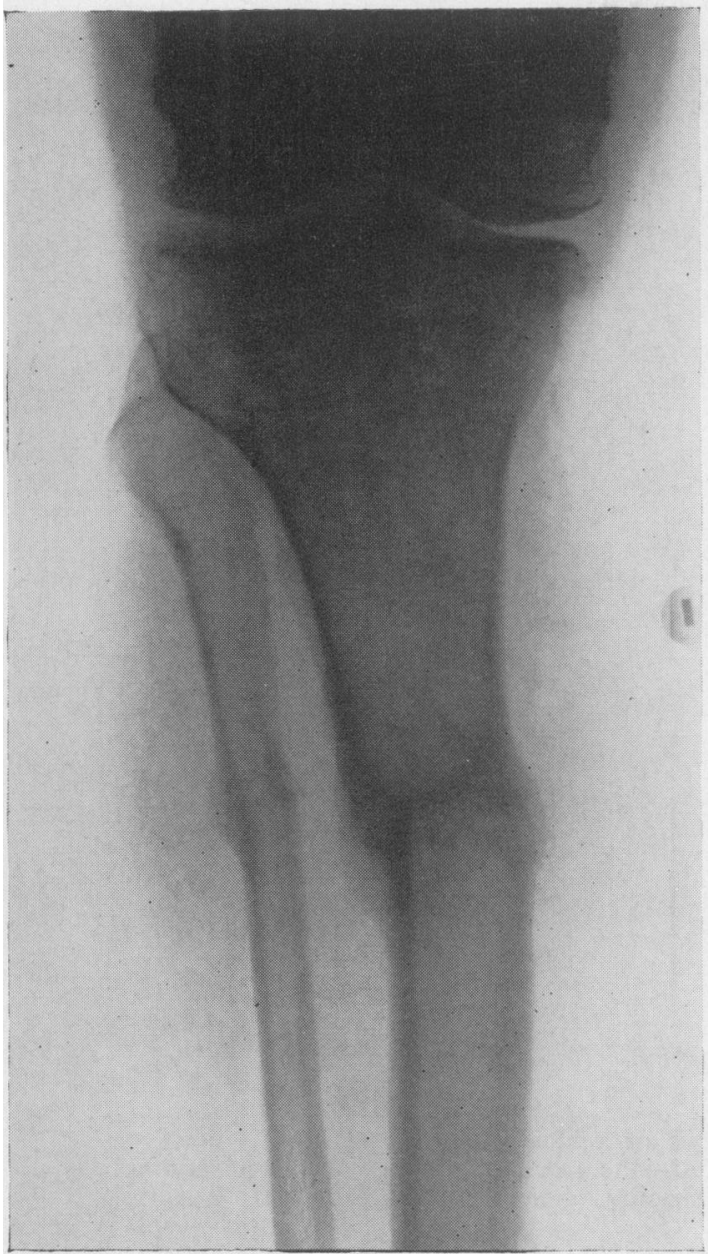

FIG. 3.-Two radiographs. the medullary barrier.

Antero-posterior

and lateral views of a tibia and fibula illustrating

synovial swelling. Radiologically the architecture of the tibial bone proximal to the site of the osteotomy tends to return to normal and joint spacing increases. The most successful cases, in which there has been restoration of full movement, are associated with the appearance of a medullary barrier in the tibia at the site of osteotomy (Fig. 3).

The lasting success of such a simple operation as osteotomy in the treatment of chronic osteoarthritis of the hip and knee raises the inevitable question-in what way does an osteotomy relieve pain and what are the physiological changes set in motion which repair the joint? No satisfactory explanation has yet appeared but certain observations which have been made, particularly in rela- tion to osteotomy of the tibia and fibulao have lead to investigations which may be useful.

\section{Investigations and Discussion}

The rapid relief of pain in chronio osteoarthritis of the hip which follows inter trochanteric osteotomy has become di commonplace. The same phenomenon occurs in chronic osteoarthritis of the knee follow ing osteotomy of the tibia and fibula. In this area of bone however, it is more easile observed that division of the tibia is constantle associated with the out-pouring of dark venous blood from the medulla; this is particularly so in elderly patients in whom the operation has been performed without a tourniquet. This 


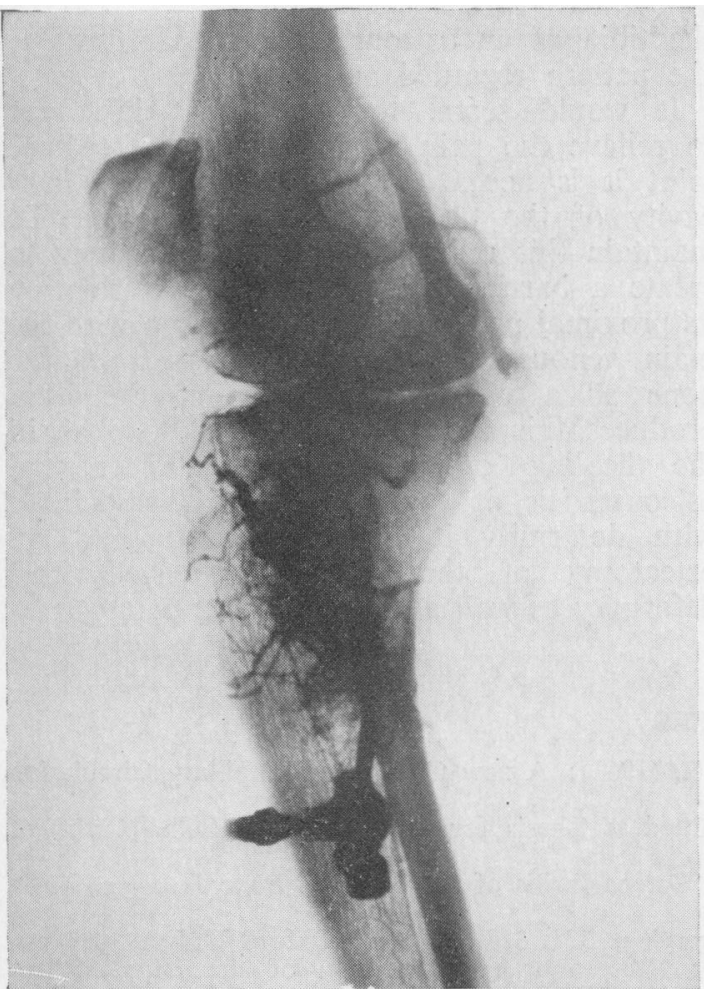

(a)

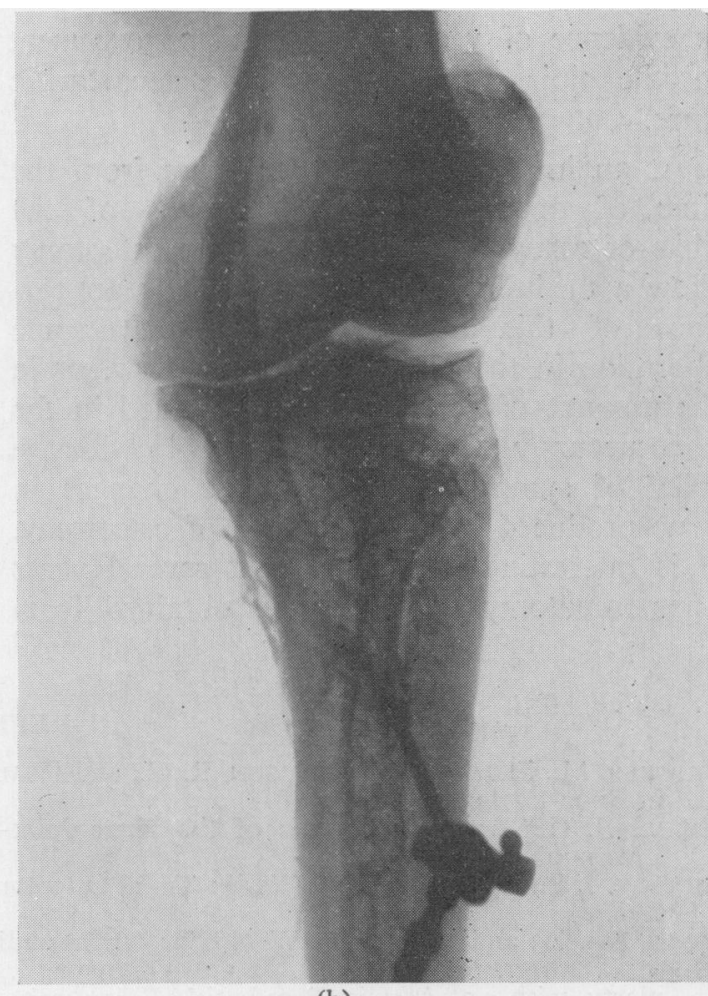

(b)

FIG. 4.-Two radiographs. Lateral views of the tibia following intra-osseus venography.

(a) The appearance in the tibia of an osteo-arthritic knee.

(b) The appearance in the tibia of an unaffected knee joint from a patient 70 years old.

appearance of venous blood suggested that the relief of intra-medullary venous pressure might be associated with the relief of pain.

In practice no reliable method of estimating the intra-medullary venous pressure has been found. Nevertheless, venous engorgement does exist within the medullæ of bones distal to chronic osteoarthritic knee joints in many patients, and certain observations (Brookes, Elkin, Harrison and Heald, 1961), which show that no valvular obstruction exists between the bone medulla and the main venous trunks of the limb, suggested that simple venous stasis might have some bearing on the matter.

This has been investigated clinically and radiologically (Helal, 1962). In all patients treated for chronic osteoarthritis of the knee at the David Lewis Northern Hospital during 1962 there was a greater percentage with associated varicose veins in the affected leg than in a comparable number of patients treated for other conditions.

Radiologically the possibilities of intraosseous venography (Schobinger, 1960) have been explored. This is a technique originally described for the delineation of main venous channels in a limb. It has been modified to produce a pattern of the venous network within bone. The procedure has proved safe and useful. The patient is tested for sensitivity by the injection of 1 cc. 45 per cent Hypaque six hours before operation. Under anæsthesia, before the osteotomy is commenced, a self-tapping cannula (Helal, 1962) is screwed into the tibial medulla and the backflow of medullary blood is noted. 10 ccs. of 45 per cent Hypaque are then injected into the tibia and an X-ray taken just as the injection is completed. Fig. 4 shows the type of venogram obtained in an established osteoarthritic knee contrasted with that obtained from the tibia of a patient from whose knee a large ganglion was being removed. This latter picture can probably be regarded as a normal intraosseous venogram. Provided that the radiograph is taken immediately the injection is completed this venous pattern in the bone can be obtained, although it does not appear in any of Schobinger's illustrations, where radiography was delayed. Undoubtedly, there 
is evidence of venous sinusoidal engorgement in the tibia subjacent to an osteoarthritic knee.

At an interval such as two years from the time of operation the radiographs of the tibix of many patients subjected to osteotomy show a medullary block (Fig. 3). The appearance of this barrier suggests that some alteration in the pattern of venous flow, or in the amount of venous blood contained in the bone occurs, which has a relationship with the relief of symptoms and the late changes in bone produced by the operation of osteotomy. It is interesting to observe that several years after osteotomy the venogram obtained from the tibia of an osteoarthritic knee returns te
the pattern regarded as normal.

It would seem, therefore, that in order to relieve the pain of an osteoarthritic kne joint it is necessary to open the medullary cavity of the tibia distal to that joint. T\& maintain this relief of pain it is necessary to create a barrier across the medulla isolating its proximal part from any connection with the main venous outflow from the shaft of th\& bone as a whole. Osteotomy of the tibis produces this block naturally by bone as inthe healing of any fracture. When the osteoarthritis of the knee joint is associates with deformity it is necessary to add aff osteotomy of the fibula to correct this deformity as well as to relieve the pain.

\section{REFERENCES}

Brookes, M., Elkin, A. C. Harrison, R. G., and Heald, C. B. (1961): A new Concept of Capillary Circulation in Bone Cortex, Lancet. $\mathbf{i}, 1078$.

Helal, B. (1962): Osteoarthritis of the Knee Joint-submitted as Thesis for the degree of M.Ch. (Orth.) of Liverpool University.

JACKSON, J. P., and WAUGH, W. (1961): Tibial Osteotomy for Osteoarthritis of the Knee, J. Bone Jt. Surg., 43-B 746.

JONES, SIR. R., and LOVETT, R. W. (1929): ‘Orthopædic Surgery', p. 321, 328. London: Oxford University Pre

JUDET, J., JUDET, R., LAGRANGE, J., and DUNOYER, J. (1954): 'Resection Reconstruction of the Hip; Arthoo= plasty with an Acrylic Prosthesis'. Edinburgh and London: E. \& S. Livingstone.

LISTER and MAOEWAN (1878): Osteotomy, Lancet, ii, 912.

SCHOBINGER, R. A. (1960): 'Intraosseous Venography', New York and London: Grune and Stratton.

SMILLIE, I. S. (1946): 'Injuries of the Knee Joint', Edinburgh and London: E. \& S. Livingstone. Baltimor Williams and Wilkins.

STEINDLER, A. (1940): 'Orthopædic Operations'. Springfield, Illinois: Charles C. Thomas.

THOMAS, G. E. (1964): Personal Communication.

VolKMANN, R. (1875): Osteotomy for Knee Joint Deformity, Edinb. med. J., translation from the Berl. Klin Wschr. p. 794

WARDLE, E. N. (1962): Osteotomy of the Tibia and Fibula, Surg., Gynec. Obstet., 115, 61. 